\title{
Discovering the Future Canadians Want: Insights from the We Canada Cross-country Tour
}

\author{
Aleksandra Nasteska* \\ We Canada Founder and Communications Director \\ Victoria Wee* \\ We Canada Youth Engagement Director
}

\begin{abstract}
In 1972, the first United Nations Conference on Human Environment (UNCED) was held in Stockholm, Sweden. At the conference, government officials from industrialized and developing nations met alongside civil society organizations to create the United Nations Environment Programme (UNEP). "This conference put environmental issues on the international agenda for the first time, and marked a turning point in the development of international environmental politics. It has also been recognized as the beginning of modern political and public awareness of global environmental issues" (Baylis \& Smith, 2005, pp. 454-455).

Twenty years later, the United Nations Conference on Environment and Development (UNCED), also known as the Rio Earth Summit, was held in Rio de Janeiro. One hundred and seventy two government officials participated, of which 108 were heads of state (United Nations, 1992, United Nations Conference on Environment and Development, para. 1). This conference was one of the largest gatherings of heads of state, civil society organizations, and individuals in human history to date. Stakeholders met with the purpose of charting a course for a more sustainable future. From the conference emerged agreements, most notably Agenda 21, which created a
\end{abstract}


framework for developing global, national, and regional plans for sustainability. The Rio Earth Summit has since stood as an example of what is possible when governments and citizens work together. The outcomes of this conference still affect human lives today, mainly through the United Nations Framework Convention on Climate Change meetings, which led to the Kyoto Protocol, the only legally binding agreement to cut down carbon dioxide $\left(\mathrm{CO}_{2}\right)$ emissions.

The United Nations Conference on Sustainable Development, also known as Earth Summit 2012 or Rio+20, is regarded as one of the most crucial events in United Nations history and has been referred to by the Secretary General of the United Nations (2011), Ban Ki-moon, as "the most important global meeting on sustainable development in our time" (The Future We Want, p 2).

\section{Introduction}

In June 2010, the Canadian Environmental Network (2008) put out a call to 600 partner organizations from across Canada (About Us, para. 2), inviting them to consider coordinating the participation of civil society organizations and individuals for Earth Summit 2012.

The One Earth Initiative Society, a research and advocacy group based in Vancouver, British Columbia, responded and took on a leadership role in coordinating nationwide activities for the conference. They began planning a two-year process to engage Canadians in the conference and to observe the government negotiations. One Earth facilitated a series of six strategic planning sessions in Vancouver and Ottawa to establish a framework for operations, objectives, and timelines.

\section{The Canadian Earth Summit Coalition}

In September 2010, One Earth initiated the formation of the Canadian Earth Summit Coalition (the Coalition), an informal group of academic, research, advocacy, grassroots, and nongovernmental organizations from social, environmental, and economic backgrounds. The Coalition is a nonpartisan, self-organized network that today includes over 30 Canadian organizations (We Canada, 2012, The Coalition, para. 1). The Coalition's work is primarily focused on developing policy for the conference and on advocating for its policies with the Government of Canada. 


\section{We Canada}

Shortly after, in collaboration with Pearly\&White, a boutique branding and marketing agency, One Earth co-founded We Canada, a youth-led citizen movement for Canadian leadership in sustainable development at the Earth Summit 2012 and beyond. We Canada's goals were to engage citizens in policy development and to serve as an enabling platform for ideas and action. We Canada worked to empower Canadians by demystifying the United Nations process related to the conference.

\section{Funding}

All We Canada activities were funded by donations from individuals and businesses that have demonstrated commitment to corporate social responsibility, such as Broadway Architects, a green architecture firm that contributed towards website funding, and the Sound Research Institute that contributed in-kind with complimentary video recording equipment and documentary film editing. The majority of funds raised were obtained through public events, such as the launch party held in Vancouver in November 2010 and the cross-country tour.

We Canada's most significant project, the cross-country tour Dialogues and Action for Earth Summit 2012, was funded by donations from the event attendees, universities, student unions, and the guest speakers involved. Some notable contributors were VIA Rail, Sustainable Concordia, the Political Science Club at King's University College (University of Western Ontario), University of Toronto Scarborough Campus, Dr. David Suzuki, Severn Cullis-Suzuki, and Climate Reality Canada vice-president Desirée McGraw.

United Nations Conference on Sustainable Development (Earth Summit 2012, Rio+20)

Earth Summit 2012 commemorated the 20th anniversary of the 1992 Rio Earth Summit. It was held in June 2012 in Rio de Janeiro, Brazil. More than 130 heads of state, including French president Francois Hollande and Russian president Vladimir Putin, and other high level officials such as United States Secretary of State Hilary Clinton, met in Rio de Janeiro to determine how our world will move towards a sustainable future in the next ten years. 


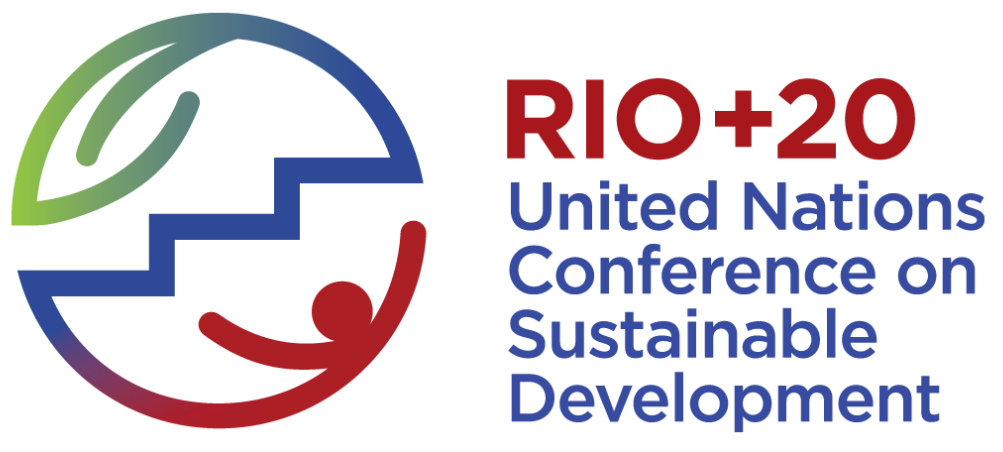

Figure 1: United Nations Conference on Sustainable Development logo

The themes of the conference were "green economy in the context of sustainable development and poverty eradication" and "institutional framework for sustainable development" (UN, 2010, Themes and Objectives, paras. 1 - 2). The conference had three main objectives:

1. Securing renewed political commitment to sustainable development;

2. Assessing the progress and implementation gaps in meeting already-agreed commitments;

3. Addressing new and emerging challenges.

\section{Dialogues and Action for Earth Summit 2012}

In February 2012, We Canada's young sustainability advocates embarked on a twomonth, cross-country tour, Dialogues and Action for Earth Summit 2012, to talk to young Canadians about the conference and the opportunity for positive change it presented.

The tour goal was to empower citizens by informing them of the past five United Nations Earth Summits and Canada's role in them, to engage the attendees in dialogues around sustainability, and to provide a platform for action. The events were mostly held at schools and universities. They each included a presentation, a consultation guided by pre-set questions, and an action piece that involved sending a letter to the Minister of Environment Peter Kent or to their local Member of Parliament. 
The tour headline speakers were Aleksandra Nasteska, who spoke in universities starting from Montreal until the last tour stop in Vancouver; Victoria Wee, who spoke in high schools and elementary schools and traveled with the troupe for the whole tour; and Marie-Pierre Daigle, who spoke in universities starting from Corner Brook until the tour mid-point in Ottawa. The tour also featured prominent guest speakers such as David Suzuki, who was a keynote speaker in Toronto at the University of Toronto Scarborough campus; Climate Reality Canada vice-president Désirée McGraw, who was a keynote speaker in Montréal at Concordia University; and ten year-old tar sands activist and singer Ta'Kaiya Blaney, who was a guest speaker in several elementary schools in the Greater Toronto Area.

The number of universities visited was 23 , and the number of schools was 30 . The total number of tour attendees was 7,837 , of which 75 per cent were youth between the ages of 10 and 25. A total of 1,129 letters were sent to political leaders, demanding that the Government of Canada make sustainable development a priority on the federal agenda or not show up at the conference. In each city, the touring troupe members were hosted by Canadian families, who contributed accommodations, meals, and local transport assistance. A full list of stops, university events, dates, and keynote speakers can be found in Appendix 1.

The results of the tour were presented in We Canada's report The Future Canadians Want during the conference in Rio de Janeiro in June 2012, at We Canada's event A Journey for Canadian Leadership at Rio+20, where Severn Cullis-Suzuki was the keynote speaker.

\section{Methodology}

The series of events on the cross-country tour were designed to include the most diverse representation of views across Canada possible. The touring troupe visited 16 cities and towns. English events were held in Corner Brook in Newfoundland and Labrador; Halifax in Nova Scotia; Montreal in Québec; Ottawa, Kingston, London, Waterloo/Kitchener and Toronto in Ontario; Winnipeg in Manitoba; Saskatoon in Saskatchewan; Edmonton in Alberta; Victoria and Vancouver in British Columbia; and Whitehorse in the Yukon. French events were held in Moncton in New Brunswick, Québec City in Québec, and Ottawa in Ontario. The schools chosen were a mix of elementary, middle and high schools, both public and private, including schools in First Nations communities. The university events were open to the public, though the majority of audience members were students. 
The consultations held at the events were developed in collaboration with Shauna Sylvester, a facilitator and policy analyst at Carbon Talks, a non-profit organization from Vancouver that facilitates public dialogues on carbon tax policy. The discussion guides were based on questions related to the topics and objectives of the conference, with a goal of finding out Canadian citizens' priorities for the Earth Summit 2012.

In universities there were two questions. For the first question, the group of attendees was split in three subgroups for time management purposes. The two questions for the university dialogues were:

1. What are the Canadian values, interests, and assets that should shape Canada's international negotiations on sustainable development at the Earth Summit 2012?

2. What are some concrete suggestions for ways we can have a flourishing environment, stable economy and strong social fabric?

In elementary, middle and high schools, the questions were adjusted according to each age group. A youth-specific question was added to inspire youth to think about their involvement in global action. The following three questions guided the discussions in the schools:

1. Why is it important for youth to participate in this conference?

2. What Canadian values should shape Canada's international negotiations on sustainable development at the Earth Summit 2012?

3. What are ways we can have a flourishing environment, stable economy and strong social fabric?

One of the tools We Canada's team used to analyze and group the responses in themes and objectives was color-coding the responses during the consultation itself; the participants wrote their answers on colored sticky notes that corresponded to a particular question. For example, for the university subgroup question "What are the Canadian values that should shape Canada's international negotiations on sustainable development at the Earth Summit 2012?" the participants wrote their answers on blue sticky notes in every university event held across the country. 


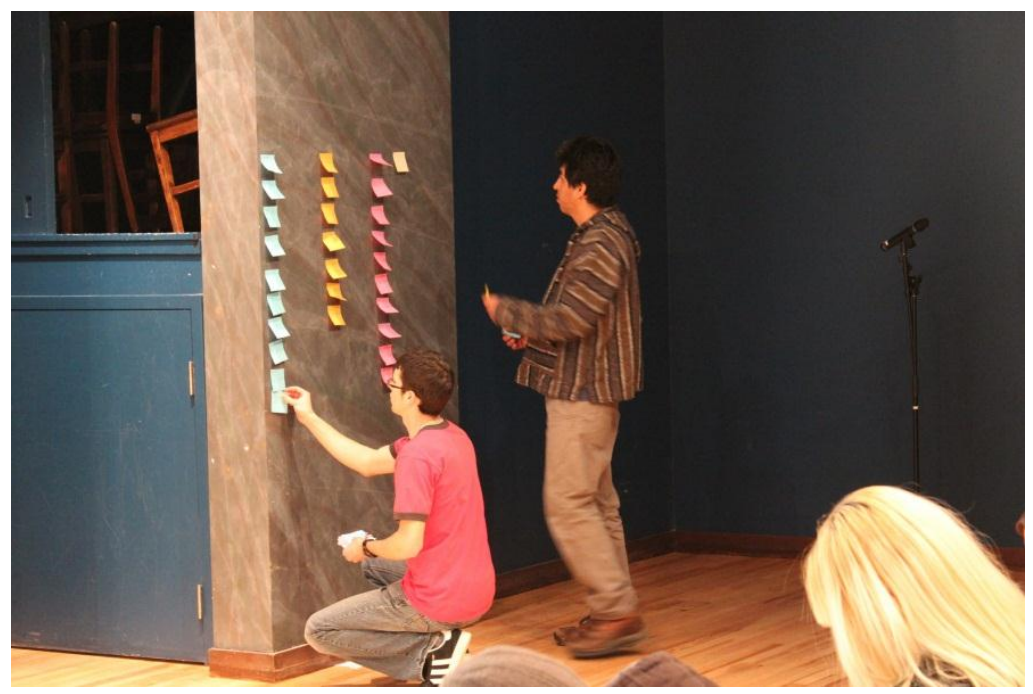

Figure 2: We Canada volunteers at University of Winnipeg grouping the sticky notes by color

Another tool the policy team used to group the consultation results in themes was word visualizations. The team members consolidated the responses for every question, divided by region and age group, and inserted them into a program called Wordle. The program was used by the team to rearrange the words by the number of highest instances of a particular word, producing an image about the most popular topic. For example, the image below is a visual representation of the responses to the question "What are the Canadian values, interests, and assets that should shape Canada's international negotiations on sustainable development at the Earth Summit 2012?” These responses were collected from the public event held in Montreal, Quebec.

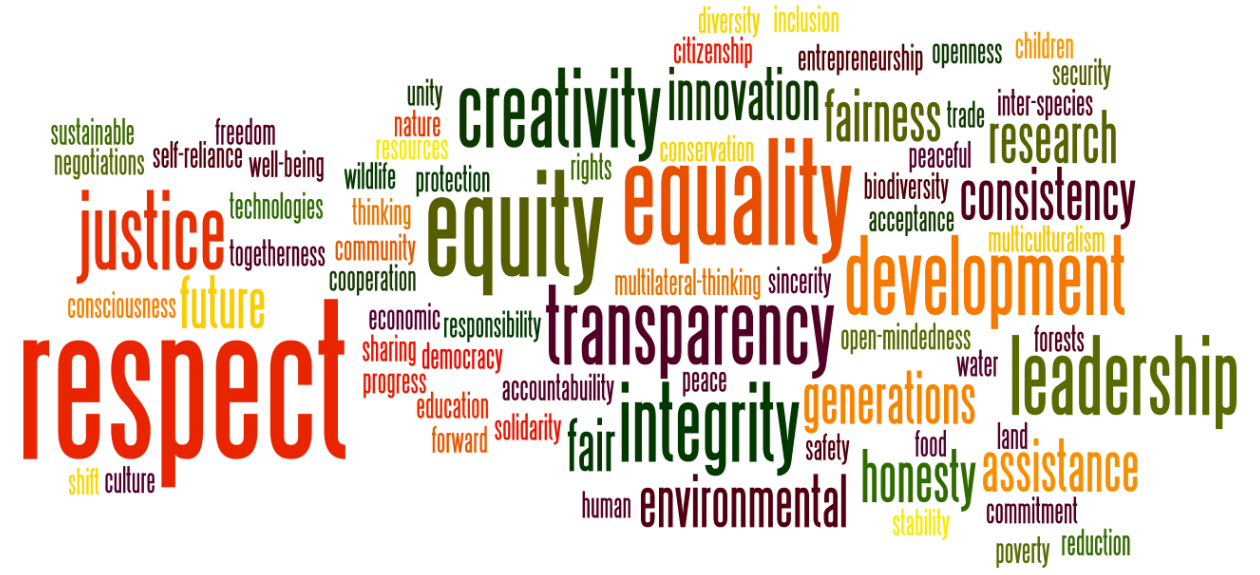

Figure 3: Word visualization of emerging themes extracted from consultation responses in Montreal, Quebec values that need to shape negotiations 


\section{Analysis of Overarching Themes}

Ten overarching themes were extracted from the qualitative data gathered at the 51 consultations conducted across Canada. They are listed by highest occurrence of the topic during the consultations.

1. Elimination of fossil fuel subsidies and stopping the oil sands

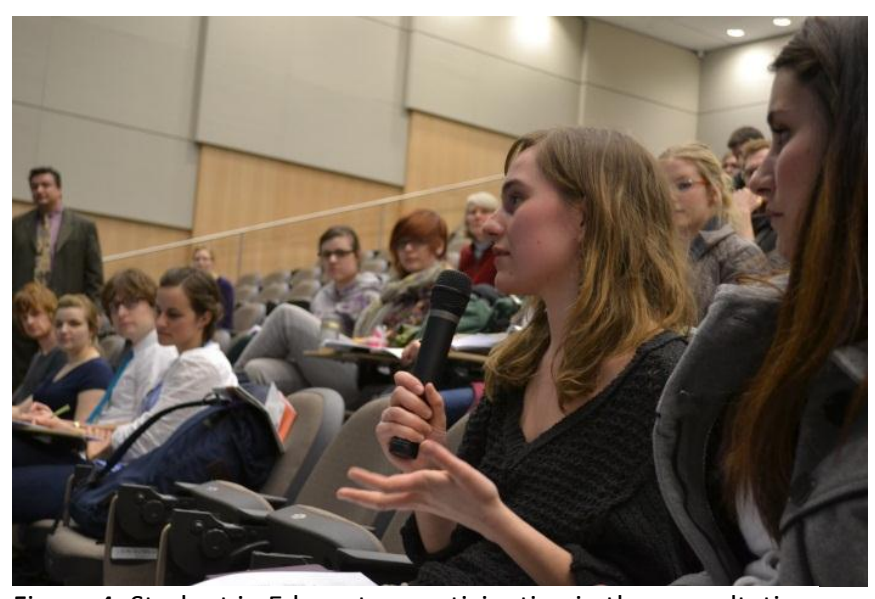

Figure 4: Student in Edmonton participating in the consultation

The first theme revolved around the elimination of fossil fuel subsidies and eradication of the oil sands and predominantly indicated the identification of "taxing carbon" as an area of interest. Although it could overlap in the areas of renewable energy and preservation of natural resources, this theme also included a call to end "fracking" - defined by the United States Environmental Protection Agency as "a well stimulation process used to maximize the extraction of underground resources; including oil, natural gas, geothermal energy and even water" (2012, Hydraulic Fracturing Background Information, para. 1) — an end to the oil sands, and an end to dependence on oil. A participant in Edmonton, Alberta, prioritized the oil sands as an area of concern, and said that "to protect our planet, Canada needs to implement clear environmental regulations, especially on the oil sands exploitation" (participant, We Canada tour, March 14, 2012).

2. Renewable energy and reduction of energy consumption

The energy theme spoke to a major interest across Canada regarding the dramatic increase of renewable energy use, research, and investment, as well as to the introduction of local, regional, and national programs to incentivize the reduction of energy consumption per capita. A student from Corner Brook, Newfoundland and Labrador, said that "by investing in renewable resources and alternative energy, we can preserve our environment and protect that which makes this country beautiful" (high school student, We Canada tour, January 30, 2012). 


\section{Green communities and eco-conservation}

"Green communities and eco-conservation" captured a range of interests from the conservation of natural resources and wildlife protection, to the greening of communities through eco-infrastructure, local farming, community gardens, creation of green space, and better investment in public transit and other transportation alternatives. One participant in Montreal, Québec, said that "conservation of the environment is key for Canada's protection of its own biodiversity" (participant, We Canada tour, February 15, 2012).

\section{Water usage and protection of water sources}

The fourth item of concern among citizens involved how water is used and how water sources are protected. With water identified as both one of the country's greatest assets and greatest values, many of those who raised water as a priority would like to see Canada reduce its internal exploitation of water sources through accountability programmes and eliminate the use of bottled water. A student in Winnipeg, Manitoba, said that "we need our water supply to sustain health and life expectancy" (middle school student, We Canada tour, March 6, 2012).

5. Youth participation and issues

In 1981, the United Nations defined "youth" as persons between fifteen and twenty-four years of age, and "children" as persons under the age of fourteen (What does the UN mean by "youth," para. 1). Today, the United Nations estimates that youth comprise $18 \%$ of the world's population, and children (aged five to fourteen years) comprise 19.8\% (2012, How many youth are there in the world today?, para. 1). With such a staggering number of humans tending toward the lower range of the age spectrum, it is hardly a surprise that many Canadian consultations highlighted young people as important factors in sustainable development issues. Foremost, Canadians would like to see a greater role played by youth in shaping a better tomorrow through political advocacy and inclusion in political processes. An elementary school student from London, Ontario, said that "if people can see that children recognize the problem, they will have stronger motivation to change themselves" (elementary school student 2012, We Canada tour, February 28, 2012). Canadians would also like to see communities and governments take an interest in providing a sustainable future for future generations. 
6. Policy recommendations

During consultations, participants often submitted policy recommendations for policy-makers at all levels. Proposals included concrete recommendations for political action or change, the adoption of new and old policies, and the inclusion of important political actors, particularly the diverse groups that represented citizens in political discussion and policy change. Much of the focus in these recommendations was on subsidising renewable energy sources, making trade more fair, developing and adopting better global standards than Gross Domestic Product (GDP) for measuring collective human well-being beyond economic progress, and returning to the Kyoto Protocol in the wake of the Canadian announcement in 2011 that it intends to withdraw from the international protocol (CBC News, 2011, Canada Pulls Out of Kyoto Protocol, para. 1), which would make it the first country to do so. One participant in Vancouver suggested that we can have a flourishing environment, a stable economy, and a strong social fabric "by carbon taxing and investing funds to make sustainable energy more affordable” (participant, Vancouver, British Columbia, March 27, 2012).

7. Canadian leadership

Citizens also called on Canada to set an example for the world and to return to its role as a leader in the areas of environmental protection and peacekeeping, suggesting that Canada has become neutral or obstructionist in its current approach. Many drew attention to Canadian assets that should be protected and valued, including vast natural resources, varied topography and a diverse population. A student from Kingston, Ontario, suggested that "we are affluent and rich. We should remember our privilege when negotiating, so that other populations aren't left behind" (elementary school student, Kingston, February 21, 2012).

8. Cultural shift as an important agent of sustainable change

The eighth overarching theme identified by Canadians focused on cultural shift as an important agent of sustainable change. Predominantly, participants recognized the important roles that major groups such as indigenous peoples, children and youth, businesses, nongovernmental organizations, academic institutions, and the general population play in influencing sustainable change. Methods for achieving cultural shift included individual practices in the home such as recycling, and society-level initiatives such as investment in green business, research towards greener technologies; mass paradigm shifts in communities such as prioritizing local, equitable, fair trade goods and services; and electing, re-electing, or forming governments that pursue long-term visions for sustainable commitments. A student in Victoria, British Columbia proposed 
that "we need a new economic system that does not run off the idea that more is better" (university student, We Canada tour, March 19, 2012).

\section{Education}

Education on environmental issues figured as a significant value and interest across those who participated. Recommendations for strengthening education under the banner of sustainable development included a greater investment in public education locally and globally, education on sustainable development in the school system, rethinking the school system itself to be sustainable, and general public education for sustainable development through campaigning and raising awareness. For example, one high school student from Waterloo/Kitchener, Ontario, was insightful in suggesting that "our education should promote innovation and new ideas to solve environmental and political issues" (high school student, We Canada tour, February 23, 2012).

10. Consultation and democracy: citizen participation in decision making

The final theme centered on consultation and democracy in Canada. Canadians called for greater transparency, consistent government consultation with diverse groups, and increased encouragement of citizen participation in decision-making. For example, a university student in Ottawa suggested that "solving environmental issues is both a contribution from individuals and government" (university student, Ottawa, February 14, 2012).

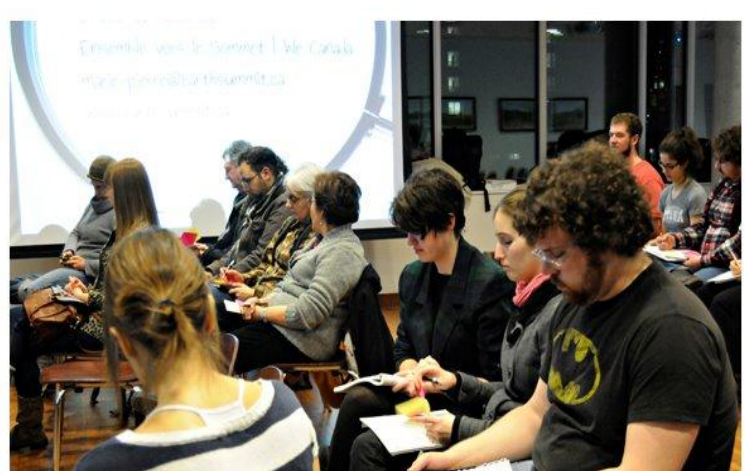

Figure 5: Participants answer questions at the consultation at the University of Ottawa

\section{Regional Priorities}

The overarching themes were prioritized differently by the students in the different regions. Below are some of the most recurring themes per region (See Table 1). Some themes that were not the top themes as described above, such as humanitarian issues, still occurred as priority in some regions. The humanitarian issues theme was mainly focused on investment in sustainable development and improvements in healthcare, gender inequality, conflict, the economic downturn, and global poverty. 


\begin{tabular}{|c|c|}
\hline & Recurring Themes Per Region \\
\hline East Coast & $\begin{array}{l}\text { - Culture shift as an important agent for sustainable change } \\
\text { - Canadian leadership - keeping promises and binding } \\
\text { agreements }\end{array}$ \\
\hline Central Canada & $\begin{array}{l}\text { - Green communities and eco-conservation } \\
\text { - Culture shift as an important agent for sustainable change }\end{array}$ \\
\hline The Prairies & $\begin{array}{l}\text { - Culture shift as an important agent for sustainable change } \\
\text { - Humanitarian issues }\end{array}$ \\
\hline Northern Canada & $\begin{array}{l}\text { - Renewable energy } \\
\text { - Reducing energy consumption }\end{array}$ \\
\hline West Coast & $\begin{array}{l}\text { - Education } \\
\text { - Green communities and eco-conservation }\end{array}$ \\
\hline
\end{tabular}

Table 1: Recurring themes per region from the We Canada cross-country tour

\section{Proposed Solutions}

Many engaging and inspired solutions were recommended by citizens for adoption in national policy in order for Canada to achieve balance between a vigorous economy, a strong social fabric, and a flourishing environment.

The Maritime provinces were notably concerned with the unevenly distributed economy of Canada which relies heavily on the regions of Central Canada and Alberta, which are rich in natural resources, tar sands, and population. Students in Moncton, New Brunswick, suggested the adoption of a national renewable energy programme, in which provinces and territories advance research and investments in specific renewable energies that capitalize on their geographical advantages. An example given was the province of British Columbia, with its coastal topography, concentrating its efforts on advancing hydroelectric, wave, and tidal power through research, international collaboration, and regional investment and subsidies. Areas with other natural advantages would develop their own regional renewable energy focuses, such as the large geothermal energy potential in the Canadian North resulting in the simultaneous 
advancement of renewable energy research and technologies for sharing best practices on a national and international scale, and the economic boost to areas currently dependent on other locations as energy sources.

On a frequent basis, the lack of a solid and consistent sustainable development foundation in public education was highlighted, particularly by schools consulted across the country. The heavily underlined solution was to integrate environmental education in all school curricula from kindergarten to grade 12. Other prominent educational recommendations were to emphasize experiential education through scholarships and subsidies, to introduce more children's books on environmental issues, to eliminate plastic bottles, to install water-bottle filling stations in schools, and to introduce compost, recycling, and waste-disposal workshops in classrooms.

Recommendations for Canada to recommit to reducing its greenhouse gas emissions, to return to its Kyoto Protocol agreements, and to participate in the elimination of the international and future generations' crisis of global climate change rose in all provinces and territories. A participant in Montreal, Québec, observed that "there are no real borders on this planet - our interest is in really acting like global citizens and behaving in the best interests of all countries and people over time and across generations" (participant, We Canada tour, February 15, 2012).

\section{Conclusion}

We Canada and the Canadian Earth Summit Coalition were the largest organized initiatives in Canada for citizen participation in the Earth Summit 2012. They connected people and organizations across the country in a vision for sustainable development and created opportunities for influencing political actors. The attempts of We Canada and the Canadian Earth Summit Coalition to change the Government of Canada's position at the conference went noticed by Canadian media such as CBC, Radio Canada, CTV, Calgary Herald, Ottawa Citizen, Montreal Gazette, Globe and Mail, Winnipeg Free Press, and Vancouver Sun. One of We Canada's attempts to truly represent Canadian voices during the conference went noticed by the global community. It was an artistic display at the main entrance of the conference premises. Namely, after We Canada's report The Future Canadians Want was completed, in collaboration with the UN, We Canada displayed all the sticky notes collected during the cross-country tour in the shape of a tree. The sticky notes were intended to be a physical representation of Canadian voices at Earth Summit 2012. Conference participants who passed by the wall were invited to pin their own visions of the future they want to build during the conference negotiations. The wall attracted the attention 
of many patrons and quickly grew into one of the conference's greatest attractions as people pinned their visions to the tree (See Figure 6).

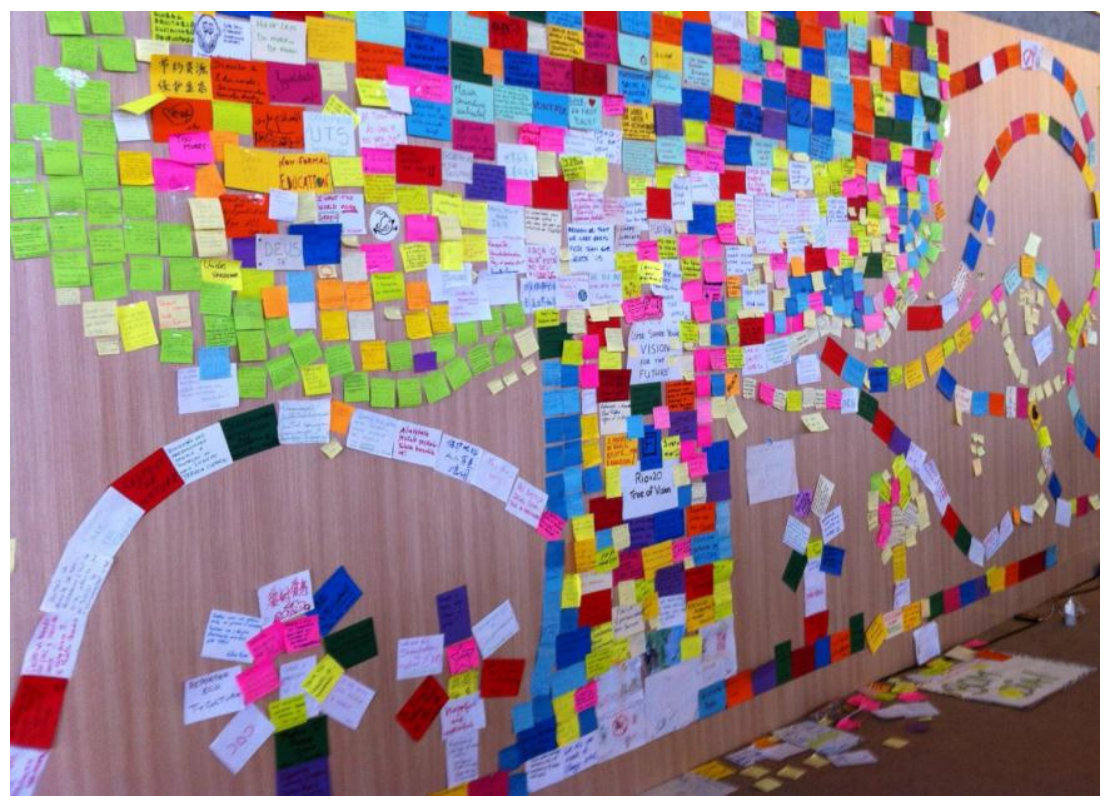

Figure 6: We Canada sticky-note "tree" at the United Nations Earth Summit 2012 in Rio - the voices of Canadians

However, the Canadian government's position at the negotiations didn't reflect any of the proposed policy recommendations or citizen priorities as recorded during the We Canada consultations. We Canada team members made it a priority to meet with the Canadian delegation at the conference and to discuss the government's point of view. The delegation chose not to meet with We Canada. Some provincial delegations such as Québec, Alberta, and Manitoba met with the We Canada team and took great interest in the report The Future Canadians Want that was presented to them during the meetings.

Through observation and reflection with respect to We Canada's voice at Earth Summit 2012, the critical conclusion that emerged was that it is through provincial governments that We Canada and the Coalition can hope to effectively pursue the consideration of Canadians' priorities and objectives for sustainable development as captured during the cross-country tour Dialogues and Action for Earth Summit 2012 (www.wecanada.org). 
*Writer: Aleksandra Nasteska is a We Canada co-founder. She studied at University Cyril and Methodius in Macedonia and V ancouver Film School in Canada. Her career in communications began as a correspondent for youth-culture television shows on the national network in Macedonia. She is the founder of Vancouver Heartbeat, a multimedia project profiling environmental and social justice leaders; media coordinator for the International Conference on the Degrowth in the Americas; and youth steering committee member for the United Nations Tunza International Youth and Children Conference 2011.

*Writer: Victoria Wee is We Canada's Youth Engagement Director and the lead organizer of We Canada's 16-city cross-country tour. She is active in the Jane Goodall Youth Council and the Canadian Environmental Network's Youth Advisory Board. Victoria coordinated an international youth declaration to the Arctic Council in 2011. Victoria was a facilitator at the United Nations Tunza Children and Youth Conference in Bandung, Indonesia, and she is We Canada's focal point to the Road to Rio+20 Coalition. Victoria is completing her undergraduate degree at Stanford University.

\section{References}

Baylis, J., and Smith, S. (2005). Globalisation of World Politics, Oxford, UK. Oxford University Press

Canadian Broadcasting Corporation. (2011, December 12). Canada pulls out of Kyoto Protocol. Retrieved from http://www.cbc.ca/news/

Canadian Earth Summit Coalition. (2011). The coalition. Retrieved from http://earthsummit.ca/partners/coalition/

Canadian Environmental Network. (2011). About us. Retrieved from http://rcen.ca/about

United Nations. (2010, September). What is Rio+20?. Retrieved from http://www.un.org/en/sustainablefuture/pdf/conf brochure.pdf

United Nations. United Nations Conference on Environment and Development. (1992). Retrieved from http://www.un.org/geninfo/bp/enviro.html

United Nations Department of Social and Economic Affairs. (2012). Youth: social policy and development division. Retrieved from http://social.un.org/index/Youth/FAQs.aspx

United Nations Department of Social and Economic Affairs. (2012). Objectives and themes. Retrieved from http://www.uncsd2012.org/rio20/objectiveandthemes.html

United States Environmental Protection Agency. (2012, May 9). Hydraulic fracturing background information. Retrieved from http://water.epa.gov/type/groundwater/uic/class2/hydraulicfracturing/wells hy drowhat.cfm 
Appendix 1: Cities, locations, dates and speakers who participated in the We Canada tour. Table 2 shows key information about the We Canada Cross-Country Tour.

\begin{tabular}{|c|c|c|c|c|}
\hline City & $\begin{array}{l}\text { University/ } \\
\text { Organization }\end{array}$ & School & Date 2012 & $\begin{array}{l}\text { University } \\
\text { Guest Speakers }\end{array}$ \\
\hline $\begin{array}{l}\text { Montreal, } \\
\text { Québec }\end{array}$ & $\begin{array}{l}\text { - Jeanne Sauvé } \\
\text { Foundation } \\
\text { - Canada World } \\
\text { Youth }\end{array}$ & & January 28 & Paul Omonge \\
\hline $\begin{array}{l}\text { Corner Brook, } \\
\text { Newfoundland } \\
\text { and Labrador }\end{array}$ & $\begin{array}{l}\text { - Memorial } \\
\text { University, Greenfell } \\
\text { Campus }\end{array}$ & $\begin{array}{l}\text { - G.C. Rowe Junior } \\
\text { - High Presentation } \\
\text { Junior High } \\
\text { - Corner Brook } \\
\text { Regional High } \\
\text { - J.J. Curling } \\
\text { Elementary }\end{array}$ & $\begin{array}{l}\text { January } \\
30-31\end{array}$ & \\
\hline $\begin{array}{l}\text { Halifax, Nova } \\
\text { Scotia }\end{array}$ & $\begin{array}{l}\text { - University of King's } \\
\text { College } \\
\text { - Dalhousie }\end{array}$ & $\begin{array}{l}\text { - Halifax Central } \\
\text { Junior High School }\end{array}$ & $\begin{array}{l}\text { February } \\
2-3\end{array}$ & \\
\hline $\begin{array}{l}\text { Moncton, New } \\
\text { Brunswick }\end{array}$ & $\begin{array}{l}\text { - Université de } \\
\text { Moncton }\end{array}$ & $\begin{array}{l}\text { - Moncton High } \\
\text { School }\end{array}$ & $\begin{array}{l}\text { February } \\
6-7\end{array}$ & \\
\hline $\begin{array}{l}\text { Québec City, } \\
\text { Québec }\end{array}$ & - Université Laval & & February 9 & Francine Richard \\
\hline $\begin{array}{l}\text { Montréal, } \\
\text { Québec }\end{array}$ & $\begin{array}{l}\text { - Sustainable } \\
\text { Concordia } \\
\text { - Student Union } \\
\text { Concordia } \\
\text { - Arts and Science } \\
\text { Federation of } \\
\text { Associations } \\
\text { - McGill School of } \\
\text { Environment }\end{array}$ & $\begin{array}{l}\text { - Vincent Massey } \\
\text { Collegiate }\end{array}$ & $\begin{array}{c}\text { February } 10 \\
-15\end{array}$ & Désirée McGraw \\
\hline Ottawa, Ontario & - Carleton University & $\begin{array}{l}\text { - } \text { Collège Saint- } \\
\text { Joseph de Hull } \\
\text { - Kanata Montessori } \\
\text { School } \\
\text { - Alta Vista Public } \\
\text { School } \\
\text { - St-Laurent Academy }\end{array}$ & $\begin{array}{c}\text { February } 14 \\
-16\end{array}$ & $\begin{array}{l}\text { - Dr. Philippé } \\
\text { Crab } \\
\text { - Geoff Green }\end{array}$ \\
\hline
\end{tabular}

ECJ Volume 2, No. 1, 2012 


\begin{tabular}{|c|c|c|c|c|}
\hline City & $\begin{array}{l}\text { University/ } \\
\text { Organization }\end{array}$ & School & Date 2012 & $\begin{array}{l}\text { University } \\
\text { Guest Speakers }\end{array}$ \\
\hline $\begin{array}{l}\text { Kingston, } \\
\text { Ontario }\end{array}$ & - Queens University & $\begin{array}{l}\text { - Bayridge Seconday } \\
\text { School } \\
\text { - Quinte Mohawk } \\
\text { School } \\
\text { - Kingston } \\
\text { Friendship Centre } \\
\text { - Kingston Native } \\
\text { High School }\end{array}$ & $\begin{array}{l}\text { February } 17 \\
-21\end{array}$ & \\
\hline $\begin{array}{l}\text { London, } \\
\text { Ontario }\end{array}$ & $\begin{array}{l}\text { - Western University } \\
\text { - King's University } \\
\text { College } \\
\text { - Political Science } \\
\text { Club }\end{array}$ & $\begin{array}{l}\text { - Centenial Private } \\
\text { School } \\
\text { - John A Macdonald } \\
\text { Secondary School } \\
\text { - St. Nicholas Private } \\
\text { School } \\
\text { - } 6 \text { Nations School }\end{array}$ & $\begin{array}{l}\text { February } 23 \\
-27\end{array}$ & $\begin{array}{l}\text { - Dr. Radoslav } \\
\text { Dimitorv }\end{array}$ \\
\hline $\begin{array}{l}\text { Waterloo, } \\
\text { Ontario }\end{array}$ & $\begin{array}{l}\text { - University of } \\
\text { Waterloo }\end{array}$ & $\begin{array}{l}\text { - Jack Chambers } \\
\text { School } \\
\text { - Clarke Road } \\
\text { Secondary School } \\
\text { - Chippewas Antler } \\
\text { River Elementary }\end{array}$ & February 28 & $\begin{array}{l}\text { - Dr. Amelia } \\
\text { Clarke }\end{array}$ \\
\hline $\begin{array}{l}\text { Toronto, } \\
\text { Ontario }\end{array}$ & $\begin{array}{l}\text { - University of } \\
\text { Toronto, St. } \\
\text { George Campus } \\
\text { - Scarborough } \\
\text { Campus }\end{array}$ & $\begin{array}{l}\text { - Cerderbrae } \\
\text { Collegiate Institute } \\
\text { - Our Lady of } \\
\text { Lourdes Catholic } \\
\text { School }\end{array}$ & $\begin{array}{l}\text { March } \\
1-5\end{array}$ & $\begin{array}{l}\text { - Raili Lakanen } \\
\text { - Dr. David } \\
\text { Suzuki }\end{array}$ \\
\hline $\begin{array}{l}\text { Winnipeg, } \\
\text { Manitoba }\end{array}$ & $\begin{array}{l}\text { - University of } \\
\text { Winnipeg }\end{array}$ & $\begin{array}{l}\text { - Lincoln Middle } \\
\text { School } \\
\text { - Maples Collegiate }\end{array}$ & $\begin{array}{l}\text { March } \\
7-8\end{array}$ & $\begin{array}{ll}\text { - } & \text { Elisabeth } \\
\text { Guibauld-Cox }\end{array}$ \\
\hline $\begin{array}{l}\text { Saskatoon, } \\
\text { Saskatchewan }\end{array}$ & $\begin{array}{l}\text { - Saskatchewan } \\
\text { University } \\
\text { - University Learning } \\
\text { Centre }\end{array}$ & & March 9 & \\
\hline
\end{tabular}

ECJ Volume 2, No. 1, 2012 


\begin{tabular}{|c|c|c|c|c|}
\hline City & $\begin{array}{l}\text { University/ } \\
\text { Organization }\end{array}$ & School & Date 2012 & $\begin{array}{l}\text { University } \\
\text { Guest Speakers }\end{array}$ \\
\hline $\begin{array}{l}\text { Edmonton, } \\
\text { Alberta }\end{array}$ & $\begin{array}{l}\text { - University of } \\
\text { Alberta Office of } \\
\text { Sustainability } \\
\text { - Grant McEwan } \\
\text { Concordia } \\
\text { - University College } \\
\text { of Alberta } \\
\text { - NAIT }\end{array}$ & $\begin{array}{l}\text { - Loren Akins Junior } \\
\text { High School } \\
\text { - École St. Stanislaus } \\
\text { School }\end{array}$ & $\begin{array}{l}\text { March } \\
13-16\end{array}$ & $\begin{array}{l}\text { - Dr. Colin } \\
\text { Soskolne } \\
\text { - Elisabeth } \\
\text { Guibauld-Cox }\end{array}$ \\
\hline $\begin{array}{l}\text { Victoria, British } \\
\text { Columbia }\end{array}$ & $\begin{array}{l}\text { - University of } \\
\text { Victoria }\end{array}$ & $\begin{array}{l}\text { - Spectrum High } \\
\text { School }\end{array}$ & $\begin{array}{l}\text { March 19, } \\
\text { March } 30\end{array}$ & \\
\hline $\begin{array}{l}\text { Whitehorse, } \\
\text { Yukon }\end{array}$ & - Yukon College & $\begin{array}{l}\text { - École FH Collins } \\
\text { Secondary } \\
\text { - Porter Creek } \\
\text { Secondary School }\end{array}$ & March 21 & $\begin{array}{l}\text { - Dr. John } \\
\text { Streicker }\end{array}$ \\
\hline $\begin{array}{l}\text { Vancouver, } \\
\text { British } \\
\text { Columbia }\end{array}$ & $\begin{array}{l}\text { - Simon Fraser } \\
\text { University } \\
\text { - Carbon Talks } \\
\text { - One Earth }\end{array}$ & & March 27 & $\begin{array}{l}\text { - Severn Cullis- } \\
\text { Suzuki } \\
\text { - Emmanuel } \\
\text { Prinet } \\
\text { - Dr. Cathryn } \\
\text { Harrison } \\
\text { - Sasha Caldera }\end{array}$ \\
\hline
\end{tabular}




\section{Appendix 2: Acknowledgements}

Many people, organizations, and businesses contributed to make this crosscountry tour possible. We would like to thank them for the incredible support and involvement in We Canada.

We thank all the universities, high schools, elementary schools and other organisations that hosted the cross-country tour events and were listed in Appendix 1.

We also thank the following people and organizations.

\section{Main Speakers}

Aleksandra Nasteska, Victoria Wee, Marie-Pierre Daigle

\section{Facilitators}

Kristy Franks, Alexandra Lucchesi

\section{Guest Speakers}

Amber Mac, We Canada Champion, broadcast journalist, and author

Dr. Amelia Clarke, assistant professor, University of Waterloo

Dr. Colin Soskolne, professor, University of Alberta

Dr. David Suzuki, Co-founder of the David Suzuki Foundation

Désirée McGraw, We Canada Champion, and Climate Reality Canada vice-president

Elisabeth Guilbaud-Cox, head of communications at the United Nations Environment Programme Regional Office of North America

Emmanuel Prinet, We Canada co-founder, and Policy Director at the One Earth Initiative Society

Francine Richard, Director, Sustainable Development Strategies, Audits and Studies, Office of the Auditor General of Canada

Geoff Green, We Canada Champion, and founder of Students on Ice

Dr. John Streicker, science advisor for the Northern Climate ExChange

Dr. Kathryn Harrison, professor, University of British Columbia 
Paul Omonge, Sauvé Scholar at Jeanne Sauvé Foundation

Dr. Philippe Crabbé, professor emeritus, University of Ottawa

His Excellency Piragibe dos Santos Tarragô, Ambassador of Brazil to Canada

Dr. Radoslav Dimitrov, professor, University of Western Ontario

Raili Lakanen, We Canada policy development director

Sasha Caldera, Fair Trade Vancouver co-founder

Severn Cullis-Suzuki, We Canada Champion, and internationally acclaimed activist and speaker

Ta'Kaiya Blaney, We Canada Champion, activist, and singer-songwriter

\section{Host Families}

Adam Malloy and family, Waterloo

Celeste Côté, Ottawa

Elizabeth Zarpa, Halifax

Heidi Machel, London

Iris Barrington-Leigh, Edmonton

Isaac Armstrong and family, Moncton

Jim and Judy Franks, Montreal

Laura Franks and Michael Carabine, Montreal

Maureen Matthews, Winnipeg

Peter Bretscher and Calliopi Havele, Saskatoon

Steve Roddick, Whitehorse

Tim and Kimberley Loyst, Kingston

Dr. Wade Bowers, Corner Brook

\section{Sponsors}

VIA Rail, for sponsoring the train trips across the country;

The Sound Research, for sponsoring the documentary film;

Camino, for providing fair trade, equitable goods for consultation events 